\title{
Michael Gove's war on professional historical expertise: conservative curriculum reform, extreme whig history and the place of imperial heroes in modern multicultural Britain
}

\section{Matthew Watson ${ }^{1}$}

Published online: 16 May 2019

(c) The Author(s) 2019, corrected publication 2019

\begin{abstract}
Six years of continuously baiting his opponents within the history profession eventually amounted to little where it mattered most. UK Secretary of State for Education, Michael Gove, finally backtracked in 2013 on his plans to impose a curriculum for English schools based on a linear chronology of the achievements of British national heroes. His 'history as celebration' curriculum was designed to instil pride amongst students in a supposedly shared national past, but would merely have accentuated how many students in modern multicultural Britain fail to recognise themselves in what is taught in school history lessons. Now that the dust has settled on Gove's tenure as Secretary of State, the time is right for retrospective analysis of how his plans for the history curriculum made it quite so far. How did he construct an ideological' conception of expertise which allowed him to go toe-to-toe for so long with the 'professional' expertise of academic historians and history teachers? What does the content of this ideological expertise tell us about the politics of race within Conservative Party curriculum reforms? This article answers these questions to characterise Gove as a 'whig historian' of a wilfully extreme nature in his attachment to imperial heroes as the best way to teach national history in modern multicultural Britain.
\end{abstract}

Keywords Michael Gove · History wars · Ideological expertise · Whig history · Imperial heroes $\cdot$ History curriculum

Matthew Watson

matthew.g.watson@warwick.ac.uk

1 Department of Politics and International Studies, University of Warwick, Coventry CV4 7AL, UK 


\section{Introduction}

The originating myths of Britishness go back much further in time than the legal origins of Britain. One such supposedly foundational myth applauds the political instincts of the British in opting at such an early stage in their pre-history for institutions that promote individual freedoms. Yet this is to create for reasons of present-day political expedience an understanding of the past that was fundamentally unavailable at the time to participants in the struggle for civil liberties. The existence of a lineage of liberal constitutionalism stretching back to ancient times was a rhetorical device of the earliest Whigs in the late seventeenth century (Zook 2002, p. 214). It was designed to act as justification for the removal in 1688 of the last Stuart monarch, James II, depicting absolutist Stuart rule as a radical break with a lengthy national past that guaranteed the protection of individual rights (Jones 1992, pp. 1-2). However, it remains completely unclear what 'the nation' is taken to consist of in this regard. The House of Stuart was infamous to Whigs for the way it ruled over England and not Britain, and the England it ruled over was internally divided and lacked the common external enemy that much later was to figure so prominently in political constructions of the idea of a liberal constitutionalist Britishness. A socially, politically, culturally and ethnically homogeneous nation of Britons with a similarly homogeneous story to tell about itself was simply anathema to lives that were being led.

Enter stage right Michael Gove. "History, as some may know", Gove (2014a, p. 2) told one of his last hand-picked audiences as Secretary of State for Education, "is one of my passions". The qualification 'as some may know' was almost entirely unnecessary, because anybody who had followed his statements during his four-year tenure at the Department for Education would have recognised this claim as a familiar feature of his set-piece speeches. The passion he has for history should never be underestimated, but the important point for the purpose of this paper is the political claims he thought it enabled him to make. In his mind at least, it allowed him to enter debates as an equal with those whose capacity to speak on behalf of the community of professional historians had been nurtured through much more conventional academic means. His passion facilitated a selfmade construction of an 'ideological' conception of expertise, which he treated as being on a par with the professional expertise of academic historians and history teachers. That is, the fact that he cares so deeply about the 'proper' way to teach history at school was used as a self-designated resource for ensuring that his opinions on the topic were equally self-imbued with an unquestionable aura of knowing what was best for the country's children. As Young (2011, p. 273) has noted, Gove has always found it easy to get "carried away by his own enthusiasms". To Coonan (2015, p. 455), this amounted to "public pronouncements on education [which] frequently resembled those of the iconic winter robin, who defends his territory by singing fiercely from a high place”.

Just as important as this self-elevation to expert status, though, was his reduction to the status of mere opinion more conventional professional expert analysis that failed to align with his own views. The alleged equality of viewpoint that 
followed allowed him always to be on the front foot rhetorically. Whether the weight of numbers in the debate was decisively against him counted for little in this regard. Gove would repeatedly go back to a well-worn position about what was wrong with the English education system to the exasperation of historians who knew that his claims did not add up. He was able to run for so long with his preferred curriculum-whiggish though it was in the extreme-because he was temporarily able to fix the image of historical expertise as merely one opinion against another. The article has its primary contribution in showing how straightforward Conservative politicians still find it to promote imperial heroes as role models for teaching young people about the national character. Yet it also helps to reveal more about Gove's tactic_-subsequently deployed to greater effect in the 2016 EU referendum — of re-presenting professional expertise as mere opinion.

Whilst this tactic was all his own, Gove can be seen as merely the latest education minister to be entrusted to articulate the Conservative Party's preference for traditional educational methods in the so-called 'history wars'. These now date back unresolved in the UK to the 1970s. Consistent with all his Conservative predecessors, Gove took issue with what he believed to be the unpatriotic approach of history professionals to questions of Britain and Britishness. Whereas they write about an essential fragmentation of Britain overlain only relatively recently with a unifying political mythology that obscures the continual presence of multiple variants of Britishness, Gove followed earlier Conservative politicians in preaching the need to tell the single story of how Britain has come to be the unproblematic unitary entity that he considers it to be today. Whereas they worry about exclusionary effects that must necessarily follow from presenting Britishness in singular terms, he insisted that his curriculum provided a national story in which every citizen could feel the same outpourings of pride. Whereas they want to emphasise the faltering way in which the modern understanding of nationhood came together, he set civil servants the task of stipulating a linear chronology of national progress. Gove thus found himself on a well-trodden path of dissent. Since the right-wing think tank, the Centre for Policy Studies first became animated in the 1970 s by the possibility that an educational establishment existed whose approach to national history sought to talk Britain down, every MP who has held the Conservative education portfolio has activated this particular argument concerning what Gove (2010a, p. 6) called the "trashing of our past". He wanted a seamless thread of national characteristics to be brought to life via the exploits of heroes who were exemplars of the British character, "so that we can celebrate the distinguished role of these islands in the history of the world" (Gove 2010b, c. 634).

However, the liberal constitutionalist account of ancient British traditions of securing individual freedoms has both a distinct temporality and a distinct spatiality that rendered Gove's vision problematic. The idea of Britain was forged in the eighteenth century simultaneously with the idea of a Greater Britain that resulted from practices of white settler colonialism (Wellings 2016, p. 369). The rhetorical trick at that time was to present the relationship between the imperial self and the colonised other as a replica of the relationship between adults and children (Emberley 2007, p. 71). To quote Mehta (1990, p. 443), a "civilizational infantilism" was projected onto people of colour to explicitly deny them the constitutional privileges that attended 
the assumption of agential free will back home. There was no real discussion of protecting the individual freedoms of distant people of colour as part of the imperial project, because it was supposed that child-like 'natives' first had to have their interests secured by an adult-like imperial master (Chatterjee 2012, p. 179). Perhaps because of the sensitivities that this situation now evokes, or perhaps merely because subsequent processes of formal decolonisation disrupt straightforwardly linear narratives of British national achievement, the structure of empire appears to have been something from which Gove's Conservative predecessors typically shied away. Yet the heroes from which Gove believed all British children could take pride contained those who had made their name specifically in relation to Britain's imperial mission, as they subjugated people of colour to hand new territorial acquisitions to the crown.

The two main issues at hand, then, are the continuing appeal to Empire to create rhetorical structures that seek to put the 'Great' back into Great Britain, and the specific appeal to an ideological conception of historical expertise which Gove used to make such a case. In order to explore these issues further, my analysis now proceeds in three stages. In section one, I analyse the way in which Gove used a multi-tiered construction of a crisis in school history teaching to open the political space for his own interventions. Whilst paying scant regard to whether the malaise he described matched actual experiences within English schools, he attempted broad-based rhetorical entrapment designed to imbue his clearly partisan ideas about the curriculum with common-sense attributes. His objective was always to present himself as just as much an expert on curriculum matters as professional historians. I show in section two, however, that Gove's self-proclaimed expertise relied on him positioning himself in line with what Herbert Butterfield had rather disparagingly called 'whig historians' as long ago as the 1930s. If it is not bad enough that this approach to history is now widely discredited, even in the pursuit of whig history Gove rather dramatically misread the book to which he referred when presenting his chosen vision for the curriculum: Henrietta Elizabeth Marshall's 1905 book for children, Our Island Story. Section three develops this theme, contrasting Marshall's clear ambivalence towards a conventional understanding of national heroes with Gove's attempt to resuscitate those whose only claim on hero status required Britain to be placed back within the frame of its imperial past. In thus ignoring the implications of his own 'island story' for how to create a history curriculum fit for a modern multicultural society, Gove rushed in where previous equally traditionalist Conservative Secretaries of State for Education had feared to tread.

\section{Gove as history expert}

Ten months after Gove became Secretary of State for Education, England's schools watchdog, Ofsted (2011), published a report into the state of school-level history. Its account could have been describing a completely different world to the one that underpinned Conservative education policy at that time. As the specialist education studies literature has amply demonstrated, the schools inspectorate's History for All document struck a noticeably upbeat tone (Harris et al. 2012, p. 432; Cramsie 2015, p. 497; Peterson 2016, p. 866; Doull and Townsend 2018, p. 685). It cites statistics 
showing that the numbers taking formal examinations in history at age 16 were holding up despite an increasingly pressurised timetable, and it also cites research which showed that students welcomed the polyvocality of the current curriculum content and its associated assumptions that history could be viewed from many different perspectives simultaneously (Evans 2013b). Gove's response was merely to repeat the assertions he had been making for some years about a subject field in crisis and history professionals unable to see what was in front of their eyes. Niall Ferguson, the last high-profile historian to remain steadfastly by Gove's side during the long-running dispute over the history curriculum, sang from exactly the same song sheet. His response to the Ofsted report was to lament an "educational establishment in deep denial about the damage its beloved 'new history' has done" (Ferguson, cited in Bowen et al. 2012, p. 136). The so-called 'new history' was actually not mentioned once in the whole of the 22,000-word report.

Back in the late 1980s, when another Conservative Government was struggling to impose its chosen version of the history curriculum over the wishes of the professional community, it consistently invoked what Ball (1990, p. 18) has called "a discourse of derision" in order to popularise its cause. Gove latterly did exactly the same. In both instances, attempts were made to construct a fictitious enemy, one that took perverse delight in depriving school-age students of the wonders of a 'proper' history education. What emerges is the image of a self-serving educational elite that is impervious to both popular pressure and political common-sense, with gallant holders of the Conservative education portfolio setting out on the lonely road to dethroning it in the interests of a return to "the discipline of chronology" (Gove 2009a, p. 11). Gove's specific attack on the educational establishment focused on his belief that it had set itself to deny school-age students access to the facts relating to the events through which British nationhood had been forged-and, as a corollary, to deny them access to the essential meaning of Britishness that could only be made known through "a clear narrative" of "key events" (Gove 2010b, c. 633, 2013b, p. 4).

In a 2009 speech whilst still Shadow Secretary of State, Gove (2009a, p. 6) took the Qualification and Curriculum Development Agency to task because it "does not make its principal aim a guarantee-entitlement if you prefer-that each pupil will have access to a body of knowledge". This was a theme to which he warmed when the ministerial job became his after the 2010 General Election. Six months later, he told Parliament from the despatch box that he could be trusted to ensure that "all children gain a secure knowledge of British history" (Gove 2010b, c. 633). "[E]ssential knowledge" was then conflated with "facts" in the press release that announced the launch of the curriculum review when the Government was still only 8 months old (Gove 2011, p. 5). Whilst still in opposition, he denounced the current custodians of the system for "the remorseless retreat from rigour in the exams we set our children" (Gove 2009b, p. 4). When in government this became the need to test "knowledge" that would take the form of "rich factual detail about [the nation's] heritage" and would be examined through "the power of memorisation" (Gove 2013a, pp. 9, 10; 2013d, p. 9).

Gove faced mounting scepticism from the professional community during his tenure at the Department for Education concerning the veracity of his claims. In 
response, his attacks on his critics became increasingly ad hominem; the education studies literature tends to depict this as Gove not knowing his brief sufficiently well, journalistic and political science accounts that this was merely his temperament coming to the fore (see Guyver 2013; Tipping 2013; d'Ancona 2014; Finn 2015; Harris and Burn 2016; Mansfield 2019). In addition to his concern for why facts did not play a more substantial role in the teaching of history, he now placed a greater emphasis on the people who decreed that this should be so. He had always pointed to the dangers posed by trendily progressive "educational theorists" who believed that teachers "shouldn't be doing anything so old-fashioned as passing on knowledge ... or immersing [their students] in anything like dates in history" (Gove 2010a, p. 4). Yet he latterly took to directly mocking his opponents, including 100 academics who had written an open letter at the height of the history wars questioning his pedagogical approach, saying in response that the professors felt it was "a tragedy that the secretary of state would like children to learn things" (Gove 2013e). When in opposition, Gove (2009b, p. 4) talked generally about his desire to overturn "the defeatism, the political correctness and the entrenched culture of dumbing down" that weighed so heavily upon children's ability to learn. By the time of his last year in post, however, he appeared to have become specifically transfixed by "the guilty men and women who have deprived a generation of the knowledge they need", expressing his unconcealed contempt when describing them as "the modern Enemies of Promise" (2013c, p. 2). He dismissed as ivory tower ideologues those educational theorists he felt were "so heavily invested in the regime of low expectations and narrow horizons which they have created" (Gove 2013d, p. 2). And he bemoaned what these theorists had done to the status of the teaching profession, with teachers having been "demoted from being 'the sage on the stage' [imparting facts] to a 'guide by the side' [helping children to follow their own instincts]" (Gove 2013a, p. 3).

For someone who placed such emphasis on the allegation that facts had been allowed to go missing from the history curriculum, Gove's free-and-easy approach to the factual basis of his own position was really rather noticeable. Eminent historians took him to task for what they saw as his deliberate mischaracterisation of the existing curriculum in favour of easy wins in the eyes of a supportive right-wing press (Alexander and Weekes-Bernard 2017, pp. 482, 487). Academic research has shown consistently that students' fondness for history increases the more they feel empowered to decide for themselves on matters of political interpretation (Harris 2013, p. 400). Gove, meanwhile, presented himself as a darling of the Conservative Party Conference by insisting instead that it was in all children's interest to learn by rote the accomplishments that had made Britain great and that established the national character that they have inherited. What was his justification for taking a position that drew a positive response from only 4\% of the Historical Association's membership (Eales 2013)? "Because this is what parents want", he replied (Gove 2013d, p. 2; see also, 2013a, p. 2, 2014 a, p. 6, 2014b, p. 5), as if none of the dissenting 96\% of Historical Association members were themselves also parents. As the history wars reached a crescendo of ferocity following the publication of the much-derided draft curriculum in February 2013, Gove turned repeatedly to homespun homilies that elevated the 
abstract category of 'the parent' to the position of ultimate arbiter on what should be taught in school history lessons.

Speech after speech appealed directly to parents' wishes for their children to learn "gripping narratives" focused squarely on the achievements of "heroes", those "whose example is truly inspirational" (Gove 2013a, p. 11, 2013b, p. 4, 2013d, p. 9). This appears to be a fairly obvious attempt at rhetorical entrapment by forcing history professionals-Gove's fictitious enemy of the educational establishmentinto the uncomfortable position of having to oppose 'what every parent wants for their child'. The theory of rhetorical entrapment suggests that only a minimal condition must apply if people are to defer to an argument where once they had taken a contrary position. They do not have to be persuaded that they were previously illinformed, wrong even, only that they do not have a good answer to the proposition being presented to them (Krebs and Jackson 2007, pp. 44-7). It hardly feels natural, of course, to believe that in anything other than exceptional circumstances parents will ever knowingly and deliberately select a course of action that is not the best available for their children. In the presumed belief that his critics would not argue against something that it looked impossible to argue against, Gove attempted to secure complete rhetorical entrapment in what would otherwise almost certainly have looked like a strange meeting of minds with the early twentieth-century Christian socialist, R.H. Tawney. In a 2013 speech at the height of the history wars, he said that: "Tawney, the great progressive thinker, argued that, "what a wise parent would wish for their children, so the State must wish for all its children" (Gove 2013 d, p. 2). Here we see someone generally considered to be a divisive Secretary of State for Education try to silence his critics by equating his role in government with the image of the collective wise parent of all British children, where parents always know what is best.

Gove was consequently able to present his own expertise as at least the equal of anyone else's claim on that status. He had changed the whole nature of expertise so that it related not to the authority to speak on matters of curriculum design, but to whether, when speaking, you echoed his thoughts. Expertise was thus reduced to the voicing of opinions, with expert status withheld from those who, from his perspective, spoke as contrarians. The distribution of numbers in the debate was irrelevant in this regard. Gove could happily ignore just how many historians were hostile to his plans by name-checking a dozen who remained supportive. Evans (2013a) helpfully worked through that list to explain that: "Only three of them are actually involved in teaching history at British universities, and two of those are associated with an obscure right-wing Conservative think tank called Politeia, on whose board of advisors sits none other than Gove". Gove's response was to ridicule claims that this meant it was " "Govey' versus academia" by drawing a deliberately provocative distinction between "good academia and bad academia" (Gove 2013e). "Good academia', it perhaps hardly needs saying, was constituted by those-however fewwho agreed with his views on curriculum content. But that seems to place Evans, who had criticised him remorselessly throughout the most recent outbreak of the history wars, in the camp of 'bad academia', with his claims on expertise correspondingly revoked. Yet this was Richard Evans, until his retirement in 2014 the Regius Professor of History at the University of Cambridge, who Gove (2013d, p. 8) 
himself heaped praise on for his "superb historical account ... of the rise, rule and ruin of the Third Reich", just as he was also turning the history wars particularly personal. His diatribes against "academics' pet passions" and his construction of an unbridgeable divide between academics and parents therefore look entirely expedient (Gove 2014a, p. 6).

Gove was relentless in his depiction of an education system in hock to a discredited establishment ideology and thus generically crisis-prone, where resistance to his proposals for the history curriculum was merely symptomatic of the wider malaise (Gove 2007, p. 6, 2010a, p. 4, 2013c, p. 3, 2013f, p. 5, 2014b, p. 8). How much truth is embedded in these attacks is entirely unimportant (Smith 2017, p. 314), because truthfulness was replaced as the ultimate rationale for the crisis construction by Gove's underlying ideological purpose. All along, the history wars were a front for the particular — and particularly whiggish - political story of national lineage that he was determined to impose come what may (Middleton, cited in Bowen et al. 2012, p. 136). His was the same basic story that Conservative think tanks, politicians and newspapers had been advocating for 40 years, as theoretical work on changing understandings of Britishness and Englishness have demonstrated only too clearly (Wellings 2012; Kenny 2014; Kenny and Pearce 2018; Murphy 2018; Wellings 2019).

The contours of the political debate about what sort of British history English schoolchildren should learn can therefore be relatively easily stated. It revolved around how celebratory that history should be and how far critical commentary should be allowed to disrupt an overwhelmingly positive narrative of national achievement in the sphere of defending individual freedoms. Yet this in itself merely goes to show why the vast majority of professional historians were so concerned about Gove's plans for the curriculum. He presented the outline of an almost wholly celebratory curriculum in which the 'facts' that he claimed had been denied to previous generations of English schoolchildren could only be pieced together in distinctively whiggish terms to paint the British national past in a hugely flattering light. But in doing so he had also presented an approach to British history that had been thoroughly discredited in the eyes of historians almost a century previously. Gove had positioned himself as the key contemporary proponent of what Herbert Butterfield dismissed in the 1930s in his attack on whig history.

\section{Gove as extreme Whig Historian}

Butterfield (1950 [1931], p. 92) had suggested that the task of historians was to engage in "imaginative sympathy", through which they could rid their analyses of the influences of the political controversies of their own day whilst still "mak[ing] the past intelligible to the present". The task of historians was thus to reconstruct in as detached a manner as possible the thought processes of their analytical subjects (Hobart 1971, p. 545). Butterfield's criticism of nineteenth-century British historians was that they had become not only historians of the Victorian state, but also historians for the Victorian state. That is, the only people whose thought processes they tried to inhabit were those whose imprints on the cultural life of the nation 
were consistent with a story of national success, and the precise story they told about these national heroes provided a comforting backdrop to the reproduction of the contemporary state form. The past that emerged, according to Butterfield (1950 [1931], pp. 22-6, 96-103), was a convenient 'abridgement' suited only to facilitating speculative assessments of the past that aligned with the national self-image of the present. He warned against the tendency "to produce a scheme of general history which is bound to converge beautifully upon the present" (Butterfield 1950 [1931], p. 12). However, he found this pretty much everywhere he looked in Victorian scholarship (McIntyre 2014, p. 208). Nineteenth-century historians typically saw only the best in their own society, as if the promise of personal freedoms was the genuine lived experience for all of its members. Consequently, they chose to view the past as a series of coherent staging posts to the condition at which they assumed they had arrived in the present.

Gove's preferred curriculum represents perhaps the prime example of whig history in action today. It is very difficult to see him as anything other than an artefact of nineteenth-century thinking, despite his protestations to the contrary. "It amazes me", he said in one of his last public speeches before being relieved of his duties as Secretary of State for Education, "that some try to caricature our curriculum as backward-looking" (Gove 2014b, p. 6). His retort to his critics—“when I ask for the specifics behind criticism of our policies I don't see, or hear, evidence that stands up to scrutiny" (Gove 2014b, p. 8)-focused on the proposition that is entertained seriously by a number of cognitive scientists today that the route to understanding first passes through committing facts to memory. Yet this is to conveniently miss the point of the critics' allegations. The previous curriculum that Gove had so ridiculed for its supposedly fact-free nature was actually accompanied by an assessment regime that was weighted $70 \%$ in favour of content issues: put simply, the ability to recall facts. The critics were only ever concerned about the type of facts that the Gove curriculum emphasised.

Evans (2011, p. 10), for instance, requested greater discussion of why Department for Education civil servants were only being asked to see how the "struggles of the past" could be folded into a single national constitutional narrative about why British people today enjoy "the liberties of the present". Gove's pronouncements on the curriculum never countenanced a counter emphasis on how those struggles were exceptionally hard won in the face of significant oppression of the popular will and against the wishes of those who wanted to keep the privileges of personal freedoms to themselves. The story that Gove's curriculum was designed to tell operated on the simple assertion that British political institutions remain the best in the world, as they have always been, and that British history can therefore be reduced to the history of pioneering liberal constitutionalism (Gove 2007, p. 2). Even his maiden speech to the House of Commons played to this theme, with Gove (2005) telling his fellow MPs in true whig historical fashion that: "Historians of this House will know that our finest hour came in the seventeenth century, when we in Parliament insisted on limiting the arbitrary powers of the Executive".

There has, of course, been considerable discussion amongst historians about whether the methodological rules that Butterfield laid down in The Whig Interpretation of History are too exacting to be adhered to strictly. As Wilson and Ashplant 
(1988, p. 8) have suggested, for Butterfield, "The historical record constitutes a sort of plenum; it is the task of the historian to enter that plenum, to inhabit it, and return to the present with an accurate picture of its nature". However, this would seem to involve a process of "self-emptying" (Hall 2002, p. 732), whereby historians are fully cognisant of all the influences that they have accumulated in the present and ensure that these play no role in how they write their historical studies. After all, history in its pristine Butterfield mode is not about interpretation so much as revealing the record to the greatest possible degree. Yet despite Butterfield himself latterly showing that he was just one in a long line of historians who struggled to write history in the pristine Butterfield mode, his observations on whig history remain relevant.

Butterfield's particular concern was targeted at the routinely repeated story of how the English constitution, for all its specificity, was imagined into being as an internally consistent container for Whig politics (Butterfield 1950 [1931], pp. 39-40). As Melinda Zook has shown to great effect, the earliest Whigs were only too conscious of their own role in history. They were writing just after the overthrow of the Stuart monarchy in 1688, and they had their own Whig heroes in mind as those few who were willing to make the ultimate sacrifice to defend against the tyranny of Stuart absolutism the personal freedoms that had been handed down from England's ancient constitution. Early Whig martyrology was designed to tug on the reader's heart strings, but equally importantly it also established the abstract characteristics of the heroes and villains of English constitutional history: noble, Protestant, humble, liberty-loving and unequivocally English for the heroes; duplicitous, Catholic, arrogant, tyrannical and very often French for the villains (Zook 2002, pp. 218-223). Later Whigs followed suit by claiming the heroic characteristics as the sole preserve of Whig politicians. Butterfield, by contrast, was eager to stress that the faltering steps taken during the early modern period towards the modern English constitution resulted from party conflict and not party hegemony. He highlighted the "continual interplay and perpetual collision" between Whigs and Tories (Butterfield 1950 [1931], p. 41). Whig historians may well have laid claim to the tradition of pursuing personal freedoms when faced with absolutist monarchy, but it was not only their story to tell. Edmund Burke, for instance, part of the late eighteenthcentury 'Old Whig' faction of the House of Commons, and transposed in the twentieth century into the philosophical founder of modern conservatism, likewise viewed the Glorious Revolution of 1688 through the perspective of attempts to protect "our ancient, indisputable laws and liberties" (Burke 2003 [1790], p. 27). Butterfield, it should perhaps be noted, has been described by Wight (1953, p. 475) as "the most rounded, gentle, and unpessimistic of Burkeans".

Gove can easily be fitted into the Burkean tradition that Butterfield both reflects and was a critic of, a tradition that has represented the mainstream of Conservative Party education policy for 40 years now. Buoyed in particular by interventions from the Centre for Policy Studies, the Conservatives quickly broke from the attempt to establish a policy consensus on schooling around the 1967 Plowden Report (McKiernan 1993, p. 40). The education studies literature has named the ensuing approach that of cultural restorationism. This is an appeal to the virtues of a traditional education modelled on that of the Victorian era (Brocklehurst 2015, p. 55). The dating is 
significant. History has been described by Spongberg and Tuite (2011, p. 677) as "nineteenth-century England's most characteristic art", with the rise of history at that time coinciding directly with an important period of renewal of the previous century's exercise in nation-building (MacLaughlin 2001, p. 68). Perhaps unsurprisingly, then, when the first generation of professional historians sat down to write nineteenth-century textbooks they did so in a way that was deliberately designed to sing the praises of the nation that was being produced around them (Kumar 2003, p. 203). They took the progressivist Whig story of the development of a specifically English form of liberty within the sea of continental absolutism and presented this as the only possible narrative of national history. The Conservative Party's cultural restorationist wing thus displayed an essential whiggishness right from the outset. It was not merely the cheap political shot that Gove took it for when John White (2011, p. 27) wondered aloud: "How is it that a curriculum designed for clerks and shopkeepers in Dickens's England is at the cutting edge in 2010?"

The debate about the first history curriculum is instructive in this regard. "As my old friend Kenneth Baker also found out", Gove (2013d, p. 7) opined at the height of his own history wars, in reference to his counterpart from the late 1980s, "there is no part of the national curriculum so likely to prove an ideological battleground for contending armies as history". He was right to note the parallels, because he and Baker were of pretty much one mind when it came to using the history curriculum to define the 'we' of the British nation in tub-thumpingly whiggish terms. The community of professional historians was just as frustrated with the Conservative Secretary of State for Education back then as it was more recently. In scarcely concealed irritation, Ball (1993, p. 204) characterised the Baker curriculum in the following terms: "Britain is to be at the centre of history, a benign and progressive influence upon the world, bearer of justice and civilisation". Yeo (1990, p. 126) placed the proposed Baker curriculum in the context of the politics of its chief public cheerleader, Prime Minister Margaret Thatcher: "It would be clinging to that mother who is always talking about the Mother of Parliaments, and who keeps telling foreigners (not one of us) that neither Greeks nor French, nor anyone else, has anything to teach us (people like us) about democracy. We had a French Revolution, she told Mitterrand, in 1215". The formative British national myth that England's ancient constitution pointed unfailingly in the single direction of liberty was the backdrop that lent ostensible coherence to Baker's preferred history curriculum.

The same remained true a quarter of a century later with Gove's preferred history curriculum. The conservative philosopher Roger Scruton, a consistent reference point for Gove's proposals, argued repeatedly throughout the early 2000s for a history curriculum reflecting the fact that the English had bequeathed the notion of ordered liberty to the rest of Europe (Kenny 2015, p. 44). Scruton can be seen to follow Burke (Dooley 2009, p. xi) and, with Gove clearly following Scruton, the lineage to Butterfield at his own most whiggish seems to be complete. The path to modernity, from this perspective at least, was undoubtedly one that the English had been responsible for creating. Gove believed that he had found exactly the right book for teaching this message: Henrietta Elizabeth Marshall's 1905 Our Island Story. To celebrate the centenary of its first publication, in 2005 the right-wing think tank Civitas teamed up with the right-wing Daily Telegraph to ensure that a copy of the 
book was sent to every primary school throughout Britain (Smith and Green 2017, p. 389). Marshall's narrative appears at first glance to have been structured around a clear Whig constitutional progressivism, and it evidently appealed to those who wanted to read their own political purposes into its pages. Gove constantly nodded deferentially towards it when describing his ambitions for the history curriculum in terms of Britain's 'island story'. David Cameron, meanwhile, revealed it to be the favourite and most influential book of his childhood. However, it is not necessary to go much beyond scratching the surface of the lineage that Gove and Cameron claimed for themselves to see that nothing is particularly clear cut here. The sense of a fractured lineage extends beyond Holland's (2014) statement that "Marshall herself ... was no Tory". It goes to the heart of arguably the most fundamental contradiction of Gove's preferred curriculum: how to ground chronological national history in the actions of heroes of centuries past whilst inhabiting a notion of Britain that is suitable for a modern multicultural society.

\section{Imperial heroes and the Gove curriculum}

Gove appears to have been somewhat entranced by the notions of British heroes and by how a fact-based curriculum could be fleshed out by requiring students to learn the names, the dates and the key interventions of a select band amongst their number. The Better History Group, another pressure group much to Gove's liking, helpfully provided a series of indicative examination questions to show how to embed the focus on heroes into the assessment regime. "Why did Nelson and Wellington become national heroes?", it asked, without any reflection on whether the terrain of judgement is now sufficiently contested that English schoolchildren might want to challenge the assumption that they should treat people like Nelson and Wellington as incontrovertible national heroes (Evans 2011, p. 11). English schoolchildren are apparently to inhabit unproblematically the thought processes of these national heroes so as to discover for themselves what it means to have inherited the national character. Butterfield's (1950 [1931], ch.V) historical method of 'imaginative sympathy' thus seems to be invoked, albeit extremely narrowly so. He had suggested that the "human personality is the only entity of the historian's study" (Butterfield, cited in Hall 2002, p. 721), but with personalities of the past being examined by people of the present, Butterfield seemed prepared to meet whig historians at least halfway by saying that some sort of judgement would necessarily have to be applied in the present (Hobart 1971, p. 545). The Better History Group's indicative examination questions, by contrast, seem to exclude the possibility of explicitly moral judgement being exercised by students today, with Gove's preferred history curriculum also appearing to follow suit in asserting that there was to be no discussion of who counts as a national hero and no scope for students to volunteer their own role models for learning what it means to them to be British.

Problems immediately begin to emerge, however, because there is no evidence from the text of Our Island Story to suggest that Marshall had anywhere near the same instinctive fascination for national heroes as Gove so clearly does. Butterfield's 'imaginative sympathy' can hardly be turned into the empathy that will serve 
tomorrow's citizens well if all they are presented with at school is an island story requiring them to memorise the details of 'heroic' monarchs, politicians and warriors (Bowen, in Bowen et al. 2012, p. 132). This is the story that Gove and Cameron said could be taken directly from Marshall; Baker and Thatcher had previously emphasised the virtues of exactly the same form of rote learning. However, even though Marshall does tell a story of kings and queens and prime ministers and generals organised around the central motif of liberal constitutional history, this is only in the midst of a much more expansive cast list. Whilst Gove was busily appropriating Our Island Story as a classically conservative text, the popular historian Antonia Fraser (2005) used an article in the same Daily Telegraph that had raised money for the Civitas reprint as a reminder that her foreword to that reprint had emphasised the consciously subversive nature of Marshall's text. The judgements she passed on monarchs were palpably moral in nature, all of which were informed by her starting position that the monarchy existed to serve the people. Political leaders were also judged by standards that were more instinctively sympathetic to rebels than to rulers, and the underpinning narrative of Our Island Story is propelled by openly pacifist assumptions (Vallance 2010, pp. 4-9). So much, then, for 'heroic' monarchs, politicians and warriors as the guardians of a liberal constitutionalist tradition.

A further problem arises from who it is, in particular, that was likely to populate the category of 'hero' in Gove's preferred curriculum. One of his most animated concerns across various subject fields was that the curriculum he inherited was too modern-overly focused on the twentieth century in both its pedagogical style and its content (Gove 2009a, p. 3, 2010a, p. 4, 2014b, p. 6). Recentring the history curriculum in preceding centuries, however, meant that the heroes whose lives were called upon to drive a connected history of Britain were likely to be specifically colonial heroes. It was around such issues that Gove found another way to elevate himself to a position of expertise, from which he could talk to professional historians as their presumed equal. A lot of this, it should be remembered, came from the ridicule he felt able to pour on his political opponents within the educational establishment. One Gove mantra that proved particularly important in this regard was the 'infantilisation' of the curriculum. "Teachers can turn", he said with his critics at the Historical Association firmly in his sights, "to guidance on 'Primary pedagogy and interactive powerpoints' where it is suggested that a project about rail travel should focus on the - no doubt-highly influential historical character of George Stephenson's friend, Eddy the Teddy" (Gove 2013d, p. 7). Later in the speech he returned to the same theme by assuring his audience that the curriculum "won't be improved by taking out Clive of India and Wolfe of Quebec and replacing them with Eddy the Teddy" (Gove 2013d, p. 8). Two competing cultures of expertise were thus once again invoked: one-Gove's-associating British history with the actual actions of Clive of India and Wolfe of Quebec; the other-not Gove's-associating British history with the made-up actions of Eddy the Teddy.

However, this placed Gove on political territory that was too much even for some of his erstwhile backers. Simon Schama, originally a proponent of the kind of connected history that Gove preferred, baulked at the content being suggested. Robert Clive had risen from a junior factor responsible for company accounts to the Commander-in-Chief of the British East India Company's standing army. As his popular 
epithet 'of India' suggests, perhaps more than anyone he was responsible for the military victories that united India as a single British dominion. Gove clearly thought that this was a story of heroic achievement in which British children could today still take pride; Schama appealed to more modern-day sensibilities by describing Clive as a "sociopathic, corrupt thug", someone who made "our most dodgy bankers look like a combination of Mary Poppins and Jesus Christ" (Schama, cited in Furness 2013). The existing curriculum that drew Gove's derision was also supported by a well-received textbook that asked students to reflect on whether Clive continues to deserve the heroic status traditionally ascribed to him (Culpin et al. 2008). Moral judgement will always matter, the critics said, to how facts are received and processed.

As Yeandle (2014, p. 899) notes, the politics of curriculum design is now such that the left is much more likely than the right to make the case for a curriculum that includes discussion of imperial heroes. It does so, of course, as a means of emphasising how 'heroes' are the subjects of social construction, and how changes to society's moral standards require a focus on the way heroic status is taken away every bit as much as on the way it is conferred. Gove's entirely uncritical invocation of Clive as a legitimate British hero therefore seems to reflect a vision of national identity that can only be seen in throwback terms (Young 2011, p. 267). Early in his tenure of the education brief Gove had provided a template for who should be included on his list of heroes: those who had "ventured to the hidden corners of the globe" (Gove 2007, p. 2). Yet these people embarked on their voyages for a purpose, and that purpose is likely to receive rather different moral judgements today than when these voyages were originally undertaken. We know now the imperial world that was constructed on the back of this adventurous spirit, and we also know now where that world sits in relation to contemporary systems of ethics. Gove's island story, however, attempted to portray these events as unflinching historical facts that could be learnt and repeated but never questioned and challenged as to how well they reflected upon the national past.

Marshall's Our Island Story once again makes a very informative comparator. The preface provides abundant evidence of how the ensuing narrative is to be read and where, psychologically speaking, its departure point is to be located. The book was written, she tells us, as an elegy to home, presenting England to expat children growing up in British colonies (Marshall 2005 [1905], pp. xxi-xxii). It sought to inform the young and potentially impressionable minds of those who had never been to the Mother Country despite the emotional attachments to it that they had been brought up to observe (Garton-Ash 2009, p. 49). Marshall explicitly denied that what her readers would encounter was history in any conventional sense: the fact that it is called Our Island Story and not Our Island History is deeply significant; the fact that its opening words are "Once upon a time" equally so (Marshall 2005 [1905], p. 1). Her intention was to provide the in-group of a geographically dispersed Greater Britain with a means of visualising their place within a broader structure of belonging (Wellings 2016, p. 370). She did this through producing a story about empire where facts merged seamlessly with national myth-making to create the desired effect. Gove and Cameron might well still take their own preferred story of empire from the influence that Marshall's 
book left on their childhood selves. Yet to have believed that it simply provides the facts of a connected history is contradicted by pretty much every chapter in the book.

Marshall did not really do heroes of any traditional sort-neither Nelson nor Wellington being described using typical 'heroic' language, and Clive drawing commentary merely for the "cleverness" of his military tactics (Marshall 2005 [1905], pp. 445-7, 450-2, 425). Moreover, whilst Our Island Story and the later Our Empire Story are clearly of their age, they were not written with the imperial Tory jingoism of the early twentieth century (Holland 2014). It is noticeable, for instance, that the index refers to 'Clive in India' and not 'Clive of India' (Marshall 2005 [1905], p. 514). There were certainly frequent lapses into the stereotyping of colonised others that was such a prominent feature of intellectual life in Edwardian Britain. However, the Greater Britain that Marshall was attempting to construct in the minds of her readers was one where multiple narrative accounts were available and where empathetic relationships could develop between the bearers of those competing accounts. "The stories are not all bright", she warned readers of Our Empire Story. "How should they be? We have made mistakes, we have been checked here, we have stumbled there" (Marshall 2006 [1908], p. viii). The single voice that was to guide Gove's island story looks to be very different in comparison.

The general essence of Gove's complaints about the history curriculum would not have been out of place in any of the previous 40 years of Conservative Party politics. Yet the Conservative pioneers of the call for a return to traditional education had tried to decouple their heroes from a relationship with empire. There was always an emphasis on those who had purportedly enhanced national life by their success in military ventures against powerful European enemies (Husbands et al. 2003, p. 122). However, there was never an attempt to use the history curriculum to start a dialogue about what these European wars were for. The chain of reason was to be cut short before students could be invited to reflect upon the implications of these military engagements for the world outside Europe. They were, of course, wars fought by imperial powers with significant consequences for the future shape of the colonial world. The celebration of soldiers and sailors and the claims they made on 'new' territory on behalf of the British crown were essential to bringing life to the imperial culture that dominated Britain in the eighteenth and nineteenth centuries (Dawson 1994; Conley 2009; Berenson 2011). The celebratory tone of that culture was maintained in Conservative manifestos for a renewed emphasis on a traditional curriculum. Significantly, though, the surrounding context of international politics that gave meaning to the celebrations was left noticeably unexplained. Yeandle (2014, p. 885) suggests that this highlights essential ambiguities in the minds of Conservative thought leaders about "the usability of the imperial past". Gove might therefore be regarded as a one-of-a-kind in this regard, because he appeared to exhibit no such qualms. As his critics were only too eager to point out, though, had the preferred Gove curriculum been implemented in full it would have led to the systematic exclusion from feelings of Britishness for all students for whom the history of empire does not paint Britain in a particularly favourable light. 


\section{Conclusion}

Whig history is always politicised history and, as demonstrated by Gove's time as Secretary of State for Education, the expertise that a whig historian displays is always in the service of a particular political cause. Throughout the preceding sections, however, I have made reference to Gove's preferred curriculum rather than to the form that the curriculum now takes. This reflects the fact that his attempts at rhetorical entrapment eventually came to naught, his political bluff was called and he was forced to backtrack on many of his core objectives in the face of significant public pressure. He tried to explain away his failure by saying that the preferences he had outlined in robust manner during the history wars were merely "my opening offer in the negotiation bazaar of the curriculum". His full-scale retreat was never formally recognised in the post hoc rationalisation that "compromise" was always his objective (Gove 2013g). Smith (2017, p. 324) consequently concludes that "the spectacle of contestation was as great a prize to Gove as the curriculum itself".

As Gove's critics repeatedly pointed out, contestation was inevitable, because whig histories are always likely to prove internally inconsistent if they are not exclusionary on the matter of who can recognise themselves in the underlying narrative. They will require a clearly articulated 'outside' if they are to leave the impression of an identifiable national character. The first Whigs wilfully exploited this type of distinction when positing the existence of an authentic 'us' to which Stuart absolutism could be positioned as a threatening 'them'. Later Whigs followed suit in presenting access to a liberal constitutional tradition as the essence of the good fortune of being born British, a serendipitous state of affairs denied to overseas friend and foe alike. The pursuit of empire provided an international stage on which to project the image of British exceptionalism, with still later Whigs typically failing even to catch breath before extolling Britain's right to settle distant lands in the interests of an ostensibly civilising mission. In all of these instances, whiggish approaches to history emerged in the contrast between the presumed essence of Britishness and the claims that could be made about Britain's 'others'. What, then, should we read into Gove's extreme whig history of Britain that would have been based on a narrative of heroes undertaking exceptional deeds that highlighted an equally exceptional national character?

His preferred curriculum completely failed to recognise that 'the British' now consist of large numbers of people who whig histories traditionally have tended to treat as their 'others'. Gove made no secret of his desire to control the definition of the past for English schools: there was just one national past that required just one story, and his island story was the one way to tell it if students were to remain spellbound by what it means to be British. Anyone who makes an effort to control the definition of the past, of course, is simultaneously trying to control who has access to the prevailing image of the nation. The construction of national history is forever an attempt at constructing the 'us' who can be contrasted to a 'them'. Gove never explained why anyone should believe that a curriculum that mythologises the whiteness of the national past would resonate with 
a broad-based conception of the contemporary British 'us'. It might be expected to play well within the echo chamber of a Conservative Party Conference hall, but Conservative Party members are hardly a representative reflection of the British population as a whole. Multicultural Britain requires something rather more than an emphasis on white heroes asserting British exceptionalism in their encounters with distant people of colour.

In 2007, just as Gove was handed the shadow education brief, the Department for Communities and Local Government published a report that linked the enhancement of community cohesion in a multicultural society to a process of historical mythbusting (Harris 2013, p. 405). Gove's preferred curriculum, by contrast, seems to have wanted to reassert historical myths of white superiority. The one-size-fits-all account of British citizenship that was reflected in his island story was undoubtedly an account that privileged whiteness as the underlying marker of what it means to be British (Alexander and Weekes-Bernard 2017, p. 479). Even before the date that Gove envisaged his new curriculum coming on-stream, there was ample evidence that all English secondary school students, regardless of race, were struggling to recognise themselves in what was being taught as British history (Harris and Reynolds 2014, p. 464). This situation was, predictably, particularly marked for students of colour. In being unable to see people like themselves in the curriculum's prescribed understanding of the national past, they were denied access to what they were being told was a common thread of British citizenship. Gove's preferred curriculum would only have accentuated what was in any case already a troubling situation. It would have restricted still further the feeling of an emotional connection to tradition to only a racially privileged in-group. Establishing who 'we' are simultaneously means establishing who has to be told that they are not part of 'us'. Butterfield provided good reasons in the 1930s for why whig history should be challenged on these grounds, and Gove's attempts to remodel the history curriculum in English schools through an extreme whiggish version of British history show why Butterfield's instincts remain just as relevant today.

Acknowledgements Many people have influenced the thinking that underpins this paper, although all errors or questionable interpretations remain mine alone. I first got interested in this issue through conversations with Alex Sutton, now at Oxford Brookes, and he remains the main inspiration for having now alighted on the arguments which appear here. I also need to thank very sincerely colleagues at Warwick who have helped me on our Colonial Hangover project, a schools outreach project. They are our inspirational Widening Participation Officer, Shahnaz Akhter, Jason Dymydiuk, Sahil Dutta, John Morris and our undergraduate student research assistants over the years Nikita Shah, Honey Fafowara, Taznema Khatun, Jonas Eberhardt, Marium Rafiq, Wing Yan Hui, Alex Delameilleure and Ben Hayday.

Open Access This article is distributed under the terms of the Creative Commons Attribution 4.0 International License (http://creativecommons.org/licenses/by/4.0/), which permits unrestricted use, distribution, and reproduction in any medium, provided you give appropriate credit to the original author(s) and the source, provide a link to the Creative Commons license, and indicate if changes were made.

\section{References}

Alexander, C., and D. Weekes-Bernard. 2017. History lessons: Inequality, diversity and the national curriculum. Race Ethnicity and Education 20 (4): 478-494. 
Ball, S. 1990. Politics and policy-making in education: Explorations in policy sociology. London: Routledge.

Ball, S. 1993. Education, majorism and 'the curriculum of the dead'. Curriculum Studies 1 (2): 195-214.

Berenson, E. 2011. Heroes of empire: Five charismatic men and the conquest of Africa. Berkeley, CA: University of California Press.

Bowen, L., K. Bradley, S. Middleton, A. Mackillop, and N. Sheldon. 2012. History in the UK national curriculum. Cultural and Social History 9 (1): 125-143.

Brocklehurst, H. 2015. Educating Britain? Political literacy and the construction of national history. Journal of Common Market Studies 53 (1): 52-70.

Burke, E. 2003 [1790]. Reflections on the revolution in France. New Haven, CT: Yale University Press.

Butterfield, H. 1950 [1931]. The whig interpretation of history. Cambridge: Cambridge University Press.

Chatterjee, P. 2012. The black hole of empire: History of a global practice of power. Princeton, NJ: Princeton University Press.

Conley, M. 2009. From Jack Tar to Union Jack: Representing naval manhood in the British empire, 1870-1918. Manchester: Manchester University Press.

Coonan, R. 2015. The coalition and culture: 'Bread, circuses and Britishness'. In The coalition effect, 2010-2015, ed. A. Seldon and M. Finn. Cambridge: Cambridge University Press.

Cramsie, J. 2015. British travellers and the encounter with Britain, 1450-1700. Martelsham: Boydell and Brewer.

Culpin, C., M. Riley, and J. Byrom. 2008. The impact of empire, 2nd ed. London: Hodder Education Group.

d'Ancona, Matthew. 2014. In it together: The inside story of the coalition government. London: Penguin.

Dawson, G. 1994. Soldier heroes: British adventure, empire and the imagining of masculinities. London: Routledge.

Dooley, M. 2009. Introduction: A philosophy of love. In The Roger Scruton reader, ed. M. Dooley. London: Continuum.

Doull, K., and S. Townsend. 2018. Investigating the issues and implications of 'big picture' history: Deconstructing the 'long arc of development'. Education 3-13 46 (6): 685-699.

Eales, J. 2013. The Historical Association's response to the draft national curriculum, 24 May. www. consider-ed.org.uk/historical-associations-response-to-the-draft-national-curriculum/.

Emberley, J. 2007. Defamiliarizing the aboriginal: Cultural practices and decolonization in Canada. Toronto: University of Toronto Press.

Evans, R. 2011. The wonderfulness of us (the Tory interpretation of history). London Review of Books 33 (6): 9-12.

Evans, R. 2013a. The Mr Men game. New Statesman, 23 May. www.newstatesman.com/politics/polit ics/2013/05/mr-men-game.

Evans, R. 2013b. Michael Gove's history wars. The Guardian, 13 July. www.theguardian.com/books /2013/jul/13/michael-gove-teaching-history-wars.

Finn, M. 2015. The politics of education revisited: Anthony Crosland and Michael Gove in historical perspective. London Review of Education 13 (2): 98-112.

Fraser, A. 2005. Great stories that will bring the past to life for a new generation. Daily Telegraph, 23 June. https://www.telegraph.co.uk/comment/personal-view/3617837/Great-stories-that-will-bring -the-past-to-life-for-a-new-generation.html.

Furness, H. 2013. Hay Festival 2013: Don't sign up to Gove's insulting curriculum, Schama urges. Daily Telegraph, 30 May. http://www.telegraph.co.uk/culture/hay-festival/10090287/Hay-Festival-2013Dont-sign-up-to-Goves-insulting-curriculum-Schama-urges.html.

Garton-Ash, T. 2009. Facts are subversive: Political writing from a decade without a name. London: Atlantic Books.

Gove, M. 2005. Maiden speech to House of Commons. http://www.ukpol.co.uk/michael-gove2005-maiden-speech-in-the-house-of-commons/.

Gove, M. 2007. Speech to the Conservative party conference. http://conservative-speeches.sayit.mysoc iety.org/speech/599789.

Gove, M. 2009a. Speech to the Royal Society for the Arts. http://www.thersa.org/_data/assets/pdf_ file/0009/213021/Gove-speech-to-RSA.pdf.

Gove, M. 2009b. Speech to the Conservative party conference. http://michaelgovemp.typepad.com/files/ gove-2009-conference-speech-2.pdf.

Gove, M. 2010a. Speech to the Conservative party conference. http://conservative-speeches.sayit.mysoc iety.org/speech/601441. 
Gove, M. 2010b. Oral answers to questions: Education. http://www.publications.parliament.uk/pa/cm201 011/cmhansard/cm101115/101115-0001.htm.

Gove, M. 2011. Press release: National curriculum review launched. https://www.gov.uk/government/ news/national-curriculum-review-launched.

Gove, M. 2013a. Speech to the Social Market Foundation. http://www.smf.co.uk/michael-gove-speak s-at-the-smf.

Gove, M. 2013b. Oral statement to parliament: Curriculum, exam and accountability reform. https:// www.gov.uk/government/speeches/curriculum-exam-and-accountability-reform.

Gove, M. 2013c. I refuse to surrender to the Marxist teachers hell bent on destroying our schools: Education Secretary berates 'the new enemies of promise' for opposing his plans. http://www.dailymail. co.uk/debate/article-2298146/I-refuse-surrender-Marxist-teachers-hell-bent-destroying-schoolsEducation-Secretary-berates-new-enemies-promise-opposing-plans.html\#ixzz39VNaJncD.

Gove, M. 2013d. Speech at Brighton College. https://www.gov.uk/government/speeches/what-does-itmean-to-be-an-educated-person.

Gove, M. 2013e. Question and answer session at the National Association of Head Teachers annual conference. https://www.theguardian.com/education/2013/mar/21/michael-gove-professors-new-natio nal-curriculum.

Gove, M. 2013f. Speech to Conservative party conference. https://www.theguardian.com/politics/2013/ oct/01/michael-gove-militant-teaching-unions.

Gove, M. 2013g. Michael Gove on teaching history. Start the Week, BBC Radio 4. http://www.bbc.co.uk/ programmes/b006r9xr/episodes/downloads?page $=4$.

Gove, M. 2014a. Speech at the London Academy of Excellence. https://www.gov.uk/government/speec hes/michael-gove-speaks-out-about-securing-our-childrens-future.

Gove, M. 2014b. Speech to the Policy Exchange education conference. https://blogs.spectator. co.uk/2014/06/michael-goves-moral-mission.

Guyver, R. 2013. Landmarks with questions-England's school history wars 1967-2010 and 2010-2013. History Education Research Journal 11 (2): 59-87.

Hall, I. 2002. History, Christianity and diplomacy: Sir Herbert Butterfield and international relations. Review of International Studies 28 (4): 719-736.

Harris, R. 2013. The place of diversity within history and the challenge of policy and curriculum. Oxford Review of Education 39 (3): 400-419.

Harris, R., and K. Burn. 2016. English history teachers' views on what substantive content young people should be taught. Journal of Curriculum Studies 48 (4): 518-546.

Harris, R., C. Downey, and K. Burn. 2012. History education in comprehensive schools: using schoollevel data to interpret national patterns. Oxford Review of Education 38 (4): 413-436.

Harris, R., and R. Reynolds. 2014. The history curriculum and its personal connection to students from minority ethnic backgrounds. Journal of Curriculum Studies 46 (4): 464-488.

Hobart, M. 1971. History and religion in the thought of Herbert Butterfield. Journal of the History of Ideas 32 (4): 543-554.

Holland, T. 2014. Our island story. New statesman, 18 July, pp. 22-26.

Husbands, C., A. Kitson, and A. Pendry. 2003. Understanding history teaching. Maidenhead: Open University Press.

Jones, J.R. 1992. Introduction. In Liberty secured? Britain before and after 1688, ed. J.R. Jones. Stanford, CA: Stanford University Press.

Kenny, M. 2014. The politics of English nationhood. Oxford: Oxford University Press.

Kenny, M. 2015. The return of 'Englishness' in British political culture - the end of unions? Journal of Common Market Studies 53 (1): 35-51.

Kenny, M., and N. Pearce. 2018. Shadows of empire: The anglosphere in British politics. London: Wiley.

Krebs, R., and P.T. Jackson. 2007. Twisting tongues and twisting arms: The power of political rhetoric. European Journal of International Relations 13 (1): 35-66.

Kumar, K. 2003. The making of English national identity. Cambridge: Cambridge University Press.

MacLaughlin, J. 2001. Reimagining the nation-state: The contested terrains of nation-building. London: Pluto Press.

Mansfield, A. 2019. Confusion, contradiction and exclusion: The promotion of British values in the teaching of history in schools. The Curriculum Journal 30 (1): 40-50.

Marshall, H.E. 2005 [1905]. Our island story: A history of Britain for boys and girls. London: Civitas.

Marshall, H.E. 2006 [1908]. Our empire story. Chapel Hill, NC: Yesterday's Classics. 
McIntyre, K. 2014. Herbert Butterfield: History, providence, and skeptical politics. New York: Open Road.

McKiernan, D. 1993. History in a national curriculum: Imagining the nation at the end of the $20^{\text {th }}$ century. Journal of Curriculum Studies 25 (1): 33-51.

Mehta, U.S. 1990. Liberal strategies of exclusion. Politics and Society 18 (4): 427-454.

Murphy, P. 2018. The empire's new clothes: The myth of the commonwealth. London: Hurst.

Ofsted, 2011. History for all: History in English schools, 2007/10. London: HMSO.

Peterson, A. 2016. Different battlegrounds, similar concerns? The 'history wars' and the teaching of history in Australia and England. Compare: A Journal of Comparative and International Education 46 (6): 861-881.

Smith, G., and A. Green. 2017. The Magna Carta: 800 years of public history. In The Oxford handbook of public history, ed. J. Gardner and P. Hamilton. Oxford: Oxford University Press.

Smith, J. 2017. Discursive dancing: Traditionalism and social realism in the 2013 English history curriculum wars. British Journal of Educational Studies 65 (3): 307-329.

Spongberg, M., and C. Tuite. 2011. Introduction: The gender of Whig historiography: Women writers and Britain's past and present. Women's History Review 20 (5): 673-687.

Tipping, A. 2013. "Troops to teachers": Implications for the coalition government's approach to education policy and pedagogical beliefs and practice. Educational Studies 39 (4): 468-478.

Vallance, E. 2010. A radical history of Britain. London: Abacus.

Wellings, B. 2012. English nationalism and euroscepticism: Losing the peace. Oxford: Peter Lang.

Wellings, B. 2016. Our island story: Britain, Europe and the anglosphere alternative. Political Studies Review 14 (3): 368-377.

Wellings, B. 2019. English nationalism, Brexit and the anglosphere: Wider still and wider. Manchester: Manchester University Press.

White, J. 2011. Gove's on the bac foot with a white paper stuck in 1868. Times Educational Supplement, 21 January.

Wight, M. 1953. Liberty in the modern world: Being the third lectures on the Dunning Trust, delivered at Queen's University, Kingston, Ontario, 1952, by Herbert Butterfield. International Affairs 29 (4): $475-476$.

Wilson, A., and T.G. Ashplant. 1988. Whig history and present-centred history. Historical Journal 31 (1): $1-16$.

Yeandle, P. 2014. 'Heroes into zeroes?': The politics of (not) teaching England's imperial past. Journal of Imperial and Commonwealth History 42 (5): 882-911.

Yeo, S. 1990. The more it changes, the more it stays the same? History Workshop 30 (Autumn): 120-128.

Young, M. 2011. The return to subjects: A sociological perspective on the UK coalition government's approach to the 14-19 curriculum. The Curriculum Journal 22 (2): 265-278.

Zook, M. 2002. The restoration remembered: The first Whigs and the making of their history. The Seventeenth Century 17 (2): 213-234.

Publisher's Note Springer Nature remains neutral with regard to jurisdictional claims in published maps and institutional affiliations. 